IRA-International Journal of Education \& Multidisciplinary Studies

ISSN 2455-2526; Vol.07, Issue 03 (2017)

Pg. no. 250-260

Institute of Research Advances

http://research-advances.org/index.php/IJEMS

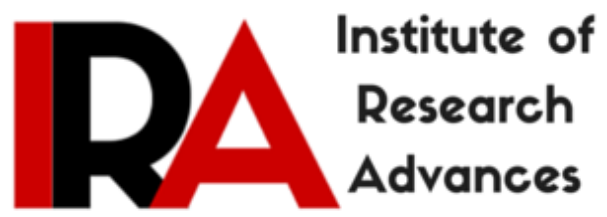

\title{
Construction and Standardization of Commerce Achievement Test for Higher Secondary Level
}

\author{
Ashish Mishra \\ Research Scholar, Department of Education, \\ University of Allahabad, Allahabad, India.
}

Type of Review: Peer Reviewed.

DOI: http://dx.doi.org/10.21013/jems.v7.n3.p10

\section{How to cite this paper:}

Mishra, A. (2017). Construction and Standardization of Commerce Achievement Test for Higher Secondary Level. IRA International Journal of Education and Multidisciplinary Studies (ISSN 2455-2526), 7(3), 250-260. doi:http://dx.doi.org/10.21013/jems.v7.n3.p10

(C) Institute of Research Advances

\section{(cc) EY-NC}

This work is licensed under a Creative Commons Attribution-Non Commercial 4.0 International License subject to proper citation to the publication source of the work.

Disclaimer: The scholarly papers as reviewed and published by the Institute of Research Advances (IRA) are the views and opinions of their respective authors and are not the views or opinions of the IRA. The IRA disclaims of any harm or loss caused due to the published content to any party. 


\begin{abstract}
Commerce education is a branch of knowledge which provides experience of business world at a large and in all its manifestations to its learners and this is basically meant to provide the students indepth knowledge of different functional areas of business and allied activities to mould the learners according to the dynamic requirements of the trade, commerce and industry. Every individual in a society is desirous to achieve something good for him and achievement in real sense is the endproduct of all human endeavours. Achievement is a pivot around which all educational phenomena move uninterruptedly. Since, Commerce stream is now being widely recognized, accepted and appreciated therefore, achievement in Commerce has become significant and its formal base generally starts with the higher secondary level of education in India. The present study is an attempt to develop and standardize a Commerce Achievement Test (CAT) for the students of higher secondary level to measure students' achievement in commerce. CAT contains seventy objective type (with multiple choice) items related to commerce subject and these items are based on syllabus of Higher Secondary Level prescribed by U. P. board, Allahabad. Validity as well as reliability of the test has been ascertained. Split-half and Kudar-Richardson Reliability of CAT have been found to be 0.93 and 0.86 respectively. The face validity has been established with the help of experts from the field of commerce and education. Concurrent validity of the test has been established against marks obtained by students in their Pre - Board Examination and it is 0.63. CAT can be administered in group setting and time-limit to finish CAT is one hour. Responses from the examinee could be taken on a separate answer-sheet. A score of 'One' is awarded for every correct answer and 'Zero' is given for wrong answers.
\end{abstract}

Key-words: Commerce Achievement Test, Construction and Standardization, Higher Secondary Level

\title{
INTRODUCTION
}

Commerce education is a branch of knowledge which provides experience of business world at a large and in all its manifestations to its learners and this is basically meant to provide the students in-depth knowledge of different functional areas of business and allied activities to mould the learners according to the dynamic requirements of the trade, commerce and industry. The basic aim of higher secondary education is to provide high quality learning as per the needs such as; skills, aptitude and interest of the learner for integration of learning with real life situation. The commerce education creates a strong foundation for those who wish to gain knowledge in specialized areas like; accountancy, management, business studies, economics, insurance, banking and finance, marketing, entrepreneurship etc. It also imparts practical approach into the learner to deal with the world of commerce such as; different form of business activities, accounting information and auditing, selection of appropriate mode of transportation etc. Every individual in a society is desirous to achieve something good for him/her and achievement in real sense is the end-product of all human endeavours. Achievement is a pivot around which all educational phenomena move uninterruptedly. Since, Commerce stream now is being widely recognized, accepted and appreciated therefore, achievement in Commerce has become significant and its formal base generally starts with the higher secondary level of education in India. According to Chesseman (1904) "Commerce education is that form of instruction which both directly and indirectly prepare the business man for his calling". So, the need arise to measure and evaluate achievement in Commerce with the help of a standardised tool because, teacher made test may not be that effective to measure achievement in a subject. Following section would be dealing with some reviews related to standardised achievement tests in Commerce and Economics authored by different investigators.

\section{REVIEW OF ACHIEVEMENT TESTS}

Anbuchelvan (2015a) developed and standardized a Basic Commerce Knowledge Test for students of 11th class studying in Government higher secondary school Tiruchengode, Tamil-Nadu. The face validity of the test had been found out by seeking opinion and suggestions from the various subject 
experts. The reliability of the test was obtained with the help of test-retest method which stands as 0.88 .

Anbuchelvan (2015b) developed and standardized an Achievement Test in Commerce for students of 11th class studying in Government higher secondary school Tiruchengode, Tamil-Nadu. The face validity of the test had been found out by seeking opinion and suggestions from the various experts/teachers of commerce. The reliability of the test was obtained with the help of test-retest method which was found to be 0.83 .

Jain (2016) developed and standardised Achievement Test in Commerce containing four Units of XI grade Commerce syllabus of schools of Hisar, Haryana. Objective type items with multiple choice (having five options) were selected for the test. Experts from the field of measurement and evaluation, experienced teachers of commerce and teacher educators were consulted to establish the content validity of the test. Preliminary try out consisted 107 items and each item carried a score of one. It was observed that most of the students took on an average 80 Minutes to answer all the questions. For the purpose of scoring, scoring key was used and one Mark (1) for a correct answer and zero (0) for an incorrect answer had been given to respondents. The final form of the achievement test contained 58 items containing Difficulty Value and Discrimination Index ranging from- 0.20 to 0.79 . Reliability was found with the help of split-half method and the coefficient of reliability was 0.86 . Contentvalidity was also established.

Osadebe (2014) developed and standardised a test in Economics for secondary school students, viz.Economics Achievement Test (EAT). It is an objective type test consists of 100 multiple choice items with five options and could be finished in two hours. The content validity of EAT was found 0.86 and 0.76 for cognitive levels or objectives and for content areas respectively. EAT was based on the course-content of Senior Secondary School Certificate Economics (SSSCE), Abraka, Nigeria, curriculum on the lines of educational objectives of Bloom's taxonomy comprising-Knowledge, Comprehension, Application, Analysis, Synthesis and Evaluation. A difficult index of 0.5 for each item was considered after applying the formula of correction for guessing. The discrimination index was established with the help of point Bi-serial statistics for each item with correction coefficient of not less than 0.3 and reliability coefficient of 0.95 was established by using Kuder-Richardson formula 20. A standard error of measurement (SEM) of 4.6 was obtained since, the SEM was low it means that EAT is highly reliable. One mark is given for right answer for an item on the other hand; zero is given for every wrong answer for a test item.

Sharma and Bhatia (2014) developed and standardized a Commerce Achievement Test (CAT) for higher secondary level students of commerce. The content validity of this test was established with the help of expert's opinion on each item. The items of this test had been selected from course prescribed by Board of Chhattisgarh. The test contains seventy-five multiple choice items divided into three parts viz.- Book-keeping and Accountancy, Applied Economics and Business Studies. The testretest reliability of this tool was found to be 0.73 . For the purpose of scoring, one mark is given against a correct response for an item on the other hand; zero is given for every incorrect response for a test item.

Sharma and Singh (2015) constructed a standardized test of achievement in Economics for IX class following the syllabus prescribed by Punjab School Education Board. The test items have been created by considering taxonomy of Bloom viz.- Knowledge, Understanding and Application, in Economics. Test items have been discussed with the teachers and assistant professors in social sciences in different colleges of education, to ascertain face validity. Every item of the test has been supplied with four options in which only one option is the correct answer. Each correct answer was given the score of 'one'. The final draft consists of 58 items representing three sections namely- Basic concepts, Economy: An Introduction \& Types and An Overview of The Indian Economy. The duration of the test had been fixed 80 minutes (including 5 minutes for instructions). Items with difficulty value as well as discriminating index ranging from $0.20-0.80$ were kept in the test. The test-retest reliability was also established which stands as 0.87 . Validity was also established by using content validity method. 
From the analysis of the above findings it can be concluded that, most of the achievement tests had been prepared either for educational boards of the other states or for other subject (i.e., Economics). That is why researcher thought it necessary to develop and standardize a Commerce Achievement Test (CAT) for Higher Secondary Students of Commerce Stream belonging to Uttar Pradesh Board of High School and Intermediate Education, Allahabad. Following sections of this study would be covering the process of development of CAT in detail.

\section{CONSTRUCTION OF COMMERCE ACHIEVEMENT TEST (CAT)}

To measure the achievement of students in Commerce an objective type test of achievement in Commerce has been developed by the investigator. This section describes the procedure of construction and standardization of Commerce Achievement Test (CAT) for intermediate class of U. P. board, Allahabad.

\section{CONSTRUCTION OF THE TRY-OUT FORM}

The investigator has studied the Textbooks of Commerce of Intermediate classes and consulted ten experienced teachers of Commerce from higher secondary schools associated with U. P. Board as well as one expert teacher educator to decide the content, objectives and type of questions to be included in the test. To ascertain optimal coverage of the syllabus, all the 25 units of prescribed syllabus were included by clubbing them to form seven units and equal weightage $(14.3 \%)$ was provided to each unit after seeking opinion of the ten subject experts from the various schools. It was decided to include 70 items in the final form of the test (CAT). So, ten items belonging to each unit have been kept in the test. This has been depicted in Table 1 .

\section{Table 1}

Weightage assigned to various content areas

\begin{tabular}{|c|c|c|}
\hline S. No. & Units/Contents & $\begin{array}{l}\text { Weightage in } \\
\text { terms of no. of } \\
\text { items }\end{array}$ \\
\hline 1 & $\begin{array}{l}\text { Accountancy: Concept and Principles, Accounting, Bills of Exchange, } \\
\text { Profit \& Loss A/c, Balance Sheet, Indian Accounting System, Capital } \\
\& \text { Revenue Reserves and Surpluses, Depreciation and Adjustment } \\
\text { Accounts. }\end{array}$ & 10 \\
\hline 2 & $\begin{array}{l}\text { Accounting for Partnership and Final Accounts of a Joint Stock } \\
\text { Company. }\end{array}$ & 10 \\
\hline 3 & Accounting for Non Trading Organizations and Ratio Analysis. & 10 \\
\hline 4 & $\begin{array}{l}\text { Commerce and Modern Civilization and Various types of Business } \\
\text { Organisations. }\end{array}$ & 10 \\
\hline 5 & Inland Trade, Intermediary Trade and Foreign Trade. & 10 \\
\hline 6 & Management, Office, Correspondence, P.C.O., Fax and Internet & 10 \\
\hline 7 & $\begin{array}{l}\text { Cheques and Exchange, Capital Market, Money and Exchange and } \\
\text { Indian Money Market }\end{array}$ & 10 \\
\hline
\end{tabular}

After consultation with ten teachers of Commerce teaching in various higher schools affiliated to U. P. Board, and one expert from the field of test-construction it was decided that items will be made for Knowledge, Comprehension and Application level objectives only. It was then decided to give 40 per cent, 40 per cent and 20 per cent weightage to questions pertaining to Knowledge, Comprehension and Application objectives respectively. Teachers of Commerce have also been asked to give their opinions/suggestions about the variety of items and after consultation with them it was decided that only multiple choice items would be included in the test. Thereafter, blue-print was prepared for CAT. Table 2 represents the blue-print for CAT. 
Table 2

Blue-print of the Commerce Achievement Test (CAT) in terms of no. of items

\begin{tabular}{|c|c|c|c|c|c|}
\hline \multirow[t]{2}{*}{ S. No. } & \multirow[t]{2}{*}{ Unit/Content } & \multicolumn{3}{|c|}{$\begin{array}{l}\text { No. of items belonging } \\
\text { to }\end{array}$} & \multirow{2}{*}{$\begin{array}{l}\text { Total } \\
\text { no. of } \\
\text { items }\end{array}$} \\
\hline & & $\mathrm{K}^{*}$ & $\mathrm{C}^{* *}$ & $\mathrm{~A} * * *$ & \\
\hline 1 & $\begin{array}{l}\text { Accountancy: Concept and Principles, Accounting, } \\
\text { Bills of Exchange, Profit \& Loss A/c, Balance } \\
\text { Sheet, Indian Accounting System, Capital \& } \\
\text { Revenue Reserves and Surpluses, Depreciation and } \\
\text { Adjustment Accounts. }\end{array}$ & 4 & 4 & 2 & 10 \\
\hline 2 & $\begin{array}{l}\text { Accounting for Partnership and Final Accounts of a } \\
\text { Joint Stock Company. }\end{array}$ & 4 & 4 & 2 & 10 \\
\hline 3 & $\begin{array}{l}\text { Accounting for Non Trading Organizations and } \\
\text { Ratio Analysis. }\end{array}$ & 4 & 4 & 2 & 10 \\
\hline 4 & $\begin{array}{l}\text { Commerce and Modern Civilization and Various } \\
\text { types of Business Organisations. }\end{array}$ & 4 & 4 & 2 & 10 \\
\hline 5 & $\begin{array}{l}\text { Inland Trade, Intermediary Trade and Foreign } \\
\text { Trade. }\end{array}$ & 4 & 4 & 2 & 10 \\
\hline 6 & $\begin{array}{l}\text { Management, Office, Correspondence, P.C.O., Fax } \\
\text { and Internet }\end{array}$ & 4 & 4 & 2 & 10 \\
\hline 7 & $\begin{array}{l}\text { Banking, Cheques and Exchange, Capital Market, } \\
\text { Money and Exchange and Indian Money Market }\end{array}$ & 4 & 4 & 2 & 10 \\
\hline & Total & 28 & 28 & 14 & 70 \\
\hline
\end{tabular}

*Knowledge, **Comprehension \& ***Application

Taking into account the aforesaid considerations 130 test items have been prepared. These items were further evaluated by the researcher and subject experts. Thus the try-out Form of the Commerce Achievement Test (CAT) consisted of 130 items.

\section{ITEM ANALYSIS}

For the purpose of tryout the tool was administered on 200 commerce students $(100$ male +100 female) of U. P. Board, studying in B.Com. Part-I classes of University of Allahabad, Allahabad in the beginning of the session. Commerce Achievement Test (CAT) has been administered in the group setting. Responses were collected on the separate answer sheet provided with the test-booklet. Scoring was done by awarding 'One' mark for every correct response and 'Zero' for every wrong response. After scoring, the answer-sheets were arranged in an ascending order of scores on Commerce Achievement Test (CAT).

27 per cent students $(\mathrm{N}=54)$ with achievement score $>77$ were included in the HIGH GROUP while 27 per cent students with achievement score $<53$ were included in the LOW GROUP. Thereafter 
number of correct responses given by each student of high and low group to each item was calculated. Difficulty Value (D. V.), and Discrimination Index (D. I.), for each item were calculated by using the following formulae-

$$
\text { Difficulty value }=\quad \frac{\mathrm{R}_{\mathrm{H}}+\mathrm{R}_{\mathrm{L}} \times 100}{2 \mathrm{~N}}
$$

where,

$$
\begin{aligned}
& \mathrm{R}_{\mathrm{H}-} \text { No. of 'right' responses in the high group. } \\
& \mathrm{R}_{\mathrm{L}-} \text { No. of 'right' responses in the low group. } \\
& \mathrm{N}-\mathrm{No} \text {. of cases in each group }
\end{aligned}
$$

Discrimination Index $=\frac{\mathrm{R}_{\mathrm{H}^{-}} \mathrm{R}_{\mathrm{L}}}{\mathrm{N}}$

where,

$\mathrm{R}_{\mathrm{H}-}$ No. of 'right' responses in the high group.

$\mathrm{R}_{\mathrm{L}-}$ No. of 'right' responses in the low group.

$\mathrm{N}-$ No. of cases in each group.

Items with difficulty value ranging from 20 per cent to 80 per cent and discrimination index ranging from 0.30 to 0.70 were selected for inclusion in the final form of the CAT. Twenty seven items with low discrimination index were modified and they were also included in the final form after reestablishing their discrimination power $(\mathrm{N}=100)$. Difficulty value and discrimination indices were reestablished. They fell within the range acceptable. Thus, the final form of CAT was prepared. The items were arranged in the descending order of difficulty values. Seventy test items have been included in the final form of the Commerce Achievement test. The test items were arranged on the basis of descending order of difficulty value i.e., from easy to difficult. The time taken by the students to complete final form of CAT has been observed at the time of final data collection by the researcher and recorded in a sheet. It was found that most of the students (90\%) took one hour to complete this test.

\section{RELIABILITY AND VALIDITY}

Split half reliability and Kuder-Richardson reliability co-efficient of the test have been calculated, it was found to be 0.93 and 0.86 respectively $(\mathrm{N}=100)$.

Face validity has been established by asking ten experts belonging to the field of Commerce as well as one expert of Educational measurement. Investigator has gone through the prescribed Textbooks of Commerce of Intermediate level and consulted ten experienced teachers of Commerce from higher secondary schools associated with U. P. Board plus one expert teacher educator for deciding the content, objectives and type of questions to be covered in the test. Concurrent validity has also been established by correlating the scores on Commerce Achievement Test and the marks obtained in PreBoard examination of Intermediate course of U. P. Board by the students (50 male and 50 female students of the Allahabad Inter College, Allahabad). It was found to be $0.63(\mathrm{~N}=100)$. 


\section{NORMS}

The Commerce Achievement Test (CAT) was administered on a sample of 600 students of commerce stream studying in class XII ${ }^{\text {th }}$ of UP Board. Statistical results for CAT have been found out and shown in Table 3.

Table 3

Statistical Results for Commerce Achievement Test (CAT)

\begin{tabular}{|l|l|l|}
\hline $\begin{array}{l}\text { Number of } \\
\text { Total } \\
\text { Students } \\
(\mathrm{N})\end{array}$ & Mean & $\begin{array}{l}\text { Standard Deviation } \\
(\mathrm{SD})\end{array}$ \\
\hline 600 & 48.68 & 6.90 \\
\hline
\end{tabular}

On the basis of aforesaid statistical results, Z-Score norms have been prepared for interpretation of raw scores obtained in Commerce Achievement Test (CAT) and the same have been shown in Table 4.

\section{Table 4}

Values of Z-Score Norms for Commerce Achievement Test (CAT)

\begin{tabular}{|c|c|c|c|c|c|}
\hline Raw Scores & Frequency & Z- Scores & Raw Scores & Frequency & Z-Scores \\
\hline 32 & 3 & -2.42 & 48 & 40 & -0.1 \\
\hline 33 & 5 & -2.27 & 49 & 51 & 0.05 \\
\hline 34 & 5 & -2.13 & 50 & 26 & 0.19 \\
\hline 35 & 13 & -1.98 & 51 & 10 & 0.34 \\
\hline 36 & 7 & -1.84 & 52 & 13 & 0.48 \\
\hline 37 & 4 & -1.69 & 53 & 41 & 0.63 \\
\hline 38 & 9 & -1.55 & 54 & 8 & 0.77 \\
\hline 39 & 11 & -1.40 & 55 & 30 & 0.92 \\
\hline 40 & 7 & -1.26 & 56 & 20 & 1.06 \\
\hline 41 & 27 & -1.11 & 57 & 36 & 1.21 \\
\hline 42 & 32 & -0.97 & 58 & 25 & 1.35 \\
\hline 43 & 26 & -0.82 & 59 & 12 & 1.50 \\
\hline 44 & 20 & -0.68 & 60 & 23 & 1.64 \\
\hline 45 & 9 & -0.53 & 61 & 3 & 1.79 \\
\hline 46 & 63 & -0.39 & 62 & 4 & 1.93 \\
\hline 47 & 16 & -0.24 & 63 & 1 & 2.08 \\
\hline
\end{tabular}

The Norms for interpretation of the level of commerce achievement have also been found out that has been given in Table 5 . 


\section{Table 5}

Norms for interpretation of the level of achievement in commerce

\begin{tabular}{|c|c|c|c|}
\hline S. No. & Range of z- scores & Grade & Level of science achievement \\
\hline 1. & +2.01 and above & A & Extremely proficiency \\
2. & +1.26 to +2.00 & B & Highly proficiency \\
3. & +0.51 to +1.25 & C & Above average proficiency \\
4. & -0.50 to 0.50 & $\mathrm{D}$ & Average proficiency \\
5. & -0.51 to -1.25 & $\mathrm{E}$ & Below average proficiency \\
6. & -1.26 to -2.00 & $\mathrm{~F}$ & Lxtremely low proficiency \\
7. & -2.01 and below & $\mathrm{G}$ & \\
& & & \\
\end{tabular}

\section{DESCRIPTION OF THE COMMEREC ACHIEVEMENT TEST (CAT)}

The present study has been conducted to develop and standardize a Commerce Achievement Test (CAT) for the students of higher secondary level to measure students' achievement in commerce. CAT contains seventy objective type (with multiple choice) items related to commerce subject and these items are based on syllabus of Higher Secondary Level prescribed by U. P. board, Allahabad. Validity as well as reliability of the test have been ascertained. Split-half and Kudar-Richardson Reliability of CAT have been found to be 0.93 and 0.86 respectively. The face validity has been established with the help of experts from the field of commerce and education. Concurrent validity of the test has been established against marks obtained by students in their Pre - Board Examination and it is 0.63. CAT can be administered in group setting and time-limit to finish CAT is one hour. Responses from the examinee could be taken on a separate answer-sheet. A score of 'One' is awarded for every correct answer and 'Zero' is given for wrong answers. CAT can be administered in group setting. Time limit of CAT is one hour. Responses can be given on the separate answer-sheet provided with the test-booklet. A score of 'One' is provided for every correct response and 'Zero' is given for wrong response. Norms (Z-score) are also available for interpretation of raw scores on this Test.

\section{Table 1}

Weightage assigned to various content areas

\begin{tabular}{|c|l|c|}
\hline S. No. & \multicolumn{1}{|c|}{ Units/Contents } & $\begin{array}{c}\text { Weightage in } \\
\text { terms of no. of } \\
\text { items }\end{array}$ \\
\hline 1 & $\begin{array}{l}\text { Accountancy: Concept and Principles, Accounting, Bills of Exchange, } \\
\text { Profit \& Loss A/c, Balance Sheet, Indian Accounting System, Capital } \\
\& \text { Revenue Reserves and Surpluses, Depreciation and Adjustment } \\
\text { Accounts. }\end{array}$ & 10 \\
\hline 2 & $\begin{array}{l}\text { Accounting for Partnership and Final Accounts of a Joint Stock } \\
\text { Company. }\end{array}$ & 10 \\
\hline 3 & \begin{tabular}{l} 
Accounting for Non Trading Organizations and Ratio Analysis. \\
\hline 4
\end{tabular} & \begin{tabular}{l} 
Commerce and Modern Civilization and Various types of Business \\
\hline
\end{tabular} \\
\hline
\end{tabular}




\begin{tabular}{|l|l|c|}
\hline & Organisations. & \\
\hline 5 & Inland Trade, Intermediary Trade and Foreign Trade. & 10 \\
\hline 6 & Management, Office, Correspondence, P.C.O., Fax and Internet & 10 \\
\hline 7 & $\begin{array}{l}\text { Cheques and Exchange, Capital Market, Money and Exchange and } \\
\text { Indian Money Market }\end{array}$ & 10 \\
\hline
\end{tabular}

Table 2

Blue-print of the Commerce Achievement Test (CAT) in terms of no. of items

\begin{tabular}{|c|c|c|c|c|c|}
\hline \multirow[t]{2}{*}{ S. No. } & \multirow[t]{2}{*}{ Unit/Content } & \multicolumn{3}{|c|}{$\begin{array}{l}\text { No. of items } \\
\text { belonging to }\end{array}$} & \multirow[t]{2}{*}{$\begin{array}{l}\text { Total no. } \\
\text { of items }\end{array}$} \\
\hline & & $\mathrm{K}^{*}$ & C** & $\mathrm{A}^{* * *}$ & \\
\hline 1 & $\begin{array}{l}\text { Accountancy: Concept and Principles, Accounting, } \\
\text { Bills of Exchange, Profit \& Loss A/c, Balance Sheet, } \\
\text { Indian Accounting System, Capital \& Revenue } \\
\text { Reserves and Surpluses, Depreciation and } \\
\text { Adjustment Accounts. }\end{array}$ & 4 & 4 & 2 & 10 \\
\hline 2 & $\begin{array}{l}\text { Accounting for Partnership and Final Accounts of a } \\
\text { Joint Stock Company. }\end{array}$ & 4 & 4 & 2 & 10 \\
\hline 3 & $\begin{array}{l}\text { Accounting for Non Trading Organizations and Ratio } \\
\text { Analysis. }\end{array}$ & 4 & 4 & 2 & 10 \\
\hline 4 & $\begin{array}{l}\text { Commerce and Modern Civilization and Various } \\
\text { types of Business Organisations. }\end{array}$ & 4 & 4 & 2 & 10 \\
\hline 5 & Inland Trade, Intermediary Trade and Foreign Trade. & 4 & 4 & 2 & 10 \\
\hline 6 & $\begin{array}{l}\text { Management, Office, Correspondence, P.C.O., Fax } \\
\text { and Internet }\end{array}$ & 4 & 4 & 2 & 10 \\
\hline 7 & $\begin{array}{l}\text { Banking, Cheques and Exchange, Capital Market, } \\
\text { Money and Exchange and Indian Money Market }\end{array}$ & 4 & 4 & 2 & 10 \\
\hline & Total & 28 & 28 & 14 & 70 \\
\hline
\end{tabular}

*Knowledge, ${ }^{* * \text { Comprehension } \& * * * \text { Application }}$

Table 3

Statistical Results for Commerce Achievement Test (CAT)

\begin{tabular}{|l|l|l|}
\hline $\begin{array}{l}\text { Number of } \\
\text { Total } \\
\text { Students } \\
(\mathrm{N})\end{array}$ & Mean & $\begin{array}{l}\text { Standard Deviation } \\
(\mathrm{SD})\end{array}$ \\
\hline 600 & 48.68 & 6.90 \\
\hline
\end{tabular}


Table 4

Values of Z-Score Norms for Commerce Achievement Test (CAT)

\begin{tabular}{|c|c|c|c|c|c|}
\hline Raw Scores & Frequency & Z- Scores & Raw Scores & Frequency & Z- Scores \\
\hline 32 & 3 & -2.42 & 48 & 40 & -0.1 \\
\hline 33 & 5 & -2.27 & 49 & 51 & 0.05 \\
\hline 34 & 5 & -2.13 & 50 & 26 & 0.19 \\
\hline 35 & 13 & -1.98 & 51 & 10 & 0.34 \\
\hline 36 & 7 & -1.84 & 52 & 13 & 0.48 \\
\hline 37 & 4 & -1.69 & 53 & 41 & 0.63 \\
\hline 38 & 9 & -1.55 & 54 & 8 & 0.77 \\
\hline 39 & 11 & -1.40 & 55 & 30 & 0.92 \\
\hline 40 & 7 & -1.26 & 56 & 20 & 1.06 \\
\hline 41 & 27 & -1.11 & 57 & 36 & 1.21 \\
\hline 42 & 32 & -0.97 & 58 & 25 & 1.35 \\
\hline 43 & 26 & -0.82 & 59 & 12 & 1.50 \\
\hline 44 & 20 & -0.68 & 60 & 23 & 1.64 \\
\hline 45 & 9 & -0.53 & 61 & 3 & 1.79 \\
\hline 46 & 63 & -0.39 & 62 & 4 & 1.93 \\
\hline 47 & 16 & -0.24 & 63 & 1 & 2.08 \\
\hline
\end{tabular}

Table 5

Norms for interpretation of the level of achievement in commerce

\begin{tabular}{|c|c|c|c|}
\hline S. No. & Range of $\mathrm{z}$ - scores & Grade & Level of science achievement \\
\hline 1. & +2.01 and above & $\mathrm{A}$ & Extremely proficiency \\
2. & +1.26 to +2.00 & $\mathrm{~B}$ & Highly proficiency \\
3. & +0.51 to +1.25 & $\mathrm{C}$ & Above average proficiency \\
4. & -0.50 to 0.50 & $\mathrm{D}$ & Average proficiency \\
5. & -0.51 to -1.25 & $\mathrm{E}$ & Below average proficiency \\
6. & -1.26 to -2.00 & $\mathrm{~F}$ & Low proficiency \\
7. & -2.01 and below & $\mathrm{G}$ & \\
& & & \\
\hline
\end{tabular}




\section{References}

1. Anastasi, A. (1976). Psychological Testing. New York: Macmillan Publishers.

2. Anbuchelvan. (2015a). Achievement in Commerce In Relation to Learning with Smart and Traditional Classes. Paripex - Indian Journal of Research, 4 (10), 96-97. Retrieved on 20.06.2017 fromhttps://www.worldwidejournals.com/paripex/file.php?val=October_2015_1444738829_31.p df

3. Anbuchelvan. (2015b). Achievement in Commerce In Relation to Learning with Smart and Traditional Classes. Paripex - Indian Journal of Research, 4 (10), 96-97. Retrieved on 20.06.2017 fromhttps://www.worldwidejournals.com/paripex/file.php?val=October_2015_1444738829_31.p df

4. Chesseman (1904). In Ranjan, R. (2013). Effective Teaching of Commerce. Retrieved on 23.09.2016 from- http://www.waymadedu.org/studentsupport/effectiveteaching.pdf

5. Gronlund, N. E. (1977). Second Edition. Constructing Achievement Tests. New Jercy. Prentice Hall.

6. Gupta, S. K. (2011). Money and Banking. Meerut: Pawan Prakashan.

7. Jain, S. (2016). A Comparative Study of the Effectiveness of Inductive Thinking Model and Mastery Learning Model on Students' Achievement in Commerce and Their Self-Concept. Retrieved on 15.06.2016 from- http://shodhganga.inflibnet.ac.in/handle/10603/114730

8. Osadebe, P. U. (2014). Construction of Economics Achievement Test for Assessment of Students. World Journal of Education, 4 (2), 58-64. Retrieved on 20.06.2017 fromhttp://dx.doi.org/10.5430/wje.v4n2p58

9. Saxena, S. C. (2011). Vyaapaarik Sangathan. Agra: Sahitya Bhavan.

10. Saxena, S. C. (2011). Vyavasaay Prabandh Kaaryaalayin Karya Vidhi Videshi Vyaapaar Evam Patra-Vyavhaar. Agra: Sahitya Bhavan.

11. Sharma, M. and Singh, G. (2015). Construction and Standardization of Achievement Test in Economics. International Journal of Science and Research, 4 (12), 2072-2074. Retrieved on 20.06.2017 from- https://www.ijsr.net/archive/v4i12/NOV152491.pdf

12. Sharma, P. and Bhatia, S. (2014). Development of Higher Secondary Level Commerce Achievement Test. Edusearch, 5 (1), 111-116.

13. Shukla, S. M. (2011). Book-keeping and Accountancy. Agra: Sahitya Bhavan. 